\title{
Warsztat POJĘCIOWy ANDrzeja Nowickiego W badANiaCh NAD HISTORIA ATEIZMU I KRYTYKI RELIGII
}

\author{
Antoni Płoszczyniec, antoniploszczyniec@gmail.com \\ Uniwersytet Wrocławski \\ plac Uniwersytecki 1, 50-137 Wrocław
}

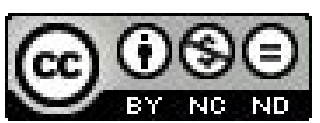

\begin{abstract}
Abstrakt
W niniejszym artykule przedstawiłem idee, których Andrzej Nowicki używał w badaniach historycznych nad ateizmem i krytyką religii. Na początku zostały pokazane marksistowskie podstawy i założenia jego religioznawstwa, nacisk został położony na jego twórcze koncepcje rozmaitych klasyfikacji krytyki religii i ateizmów oraz dystynkcję znaczeń między nimi. Zaprezentowano poszczególne dyrektywy badawcze, a osobno zostały potraktowane jego oryginalne idee badań ilościowych nad ateizmem oraz pojęć ateografii i ateoznawstwa.

Słowa kluczowe: Andrzej Nowicki, ateizm, ateografia, krytyka religii, metodologia religioznawcza, filozofia religii, historia idei
\end{abstract}

Notional workshop of Andrzej Nowicki in research on the history of atheism and critique of religion

\section{Abstract}

The this article I present ideas which Andrzej Nowicki used in historical researches on atheism and critique of religion. At the beginning, Marxist base and assumptions of his religious studies were shown, and the accent was put on his creative concepts of various classifications of critique of religion and atheism and the distinction of meanings between them. Respective research directives were presented and separately dealt with his original ideas of quantitative researches on atheism and notions of atheography and atheocompetence.

Key words: Andrzej Nowicki, atheism, atheography, critique of religion, methodology of religious studies, philosophy of religion, history of ideas

\section{WSTĘP}

Pole zainteresowań Andrzeja Nowickiego (1919-2011) było szerokie. Ten uczony, związany z Uniwersytetem Warszawskim, Uniwersytetem Wrocławskim i Uniwersytetem Marii Curii-Skłodowskiej, był znany przede wszystkim jako filozof kultury, historyk filozofii, religioznawca, badacz Renesansu, italianista oraz historyk ateizmu i krytyki religii. Był płodnym myślicielem, publikował swoje teksty od 1939 r. aż do śmierci, zostawiając po sobie ponad 50 książek i 1000 artykułów.

W niniejszym artykule skupimy się na ostatnim obszarze badawczym autora książki pt. Człowiek w świecie dzieł. Dokonamy tego poprzez prezentację, zestawienie i analizę narzędzi pojęciowych, jakie A. Nowicki stosował w badaniach nad dziejami krytyki religii. Przedstawimy także i wyjaśnimy rolę stosowanych przez niego kategorii metodologicznych oraz wyróżnianych odmian i podziałów w obrębie krytyki religii. Uwyraźnimy też znaczenie jego oryginalnych pojęć, jak ateografia, ateoznawstwo $i$ ateometria.

Zanim jednak przedstawimy bogaty warsztat metodologiczny Nowickiego, należy zasygnalizować parę faktów zjego życia. Omawiany przez nas autor nie tylko napisał wiele prac poświęconych ateizmowi i krytyce religii (m.in. Wykłady o krytyce religii, Ateizm, Wykkady o krytyce religii w Polsce), ale do samego zagadnienia podchodził z osobistym zaangażowaniem. A. Nowicki dążył do upowszechnienia zagadnień ateizmu i kontestacji religii oraz ich dziejów, o czym świadczy już fakt, że był wieloletnim redaktorem naczelnym pisma „Euhemer - Przegląd Religioznawczy” i jednym z organizatorów Polskiego Towarzystwa Religioznawczego. Poza tym, jego działalność miała charakter bardziej praktyczny. A. Nowicki był aktywnym prezesem i założycielem Stowarzyszenia Ateistów i Wolnomyślicieli, wielkim mistrzem masońskiej loży Wielkiego Wschodu Polski, członkiem ZG Towarzystwa Krzewienia Kultury Świeckiej ${ }^{1}$ oraz autorem licznych pamfletów i antyklerykalnej publicystyki (m.in. Papieże przeciw Polsce, Chłopi a biskupi).

\footnotetext{
1 Życiorys Andrzeja Nowickiego , „Euhemer-Przegląd Religioznawczy” 1979, nr 4 (114), s. 128.
} 


\section{MarksistowsKie RYSY REligioznAwStwa Nowickiego}

Autor monografii pt. Ateizm był aktywnym działaczem na rzecz krzewienia kultury świeckiej. Podstawowe idee takiej kultury odnajdywał w pismach marksistowskich, przy czym marksizm stanowił również podstawę dla jego oryginalnych koncepcji filozoficznych i religioznawczych. Filozof ten często zarzucał religii, że poprzez dogmaty homogenizuje ludzkie myśli i alienuje człowieka, co uniemożliwia stworzenie pluralistycznej kultury socjalistycznej, w której „nie tylko całe społeczeństwo byłoby podmiotem najważniejszych decyzji politycznych i ekonomicznych, ale i każdy człowiek z osobna jest rzeczywistym podmiotem, posiadającym i mogącym realizować swoje prawo do autokreacji”2

Jedną z idei, która została zaczerpnięta z filozofii Karola Marksa, Fryderyka Engelsa i Włodzimierza Lenina, był nacisk na badanie społecznych funkcji religii. Postulat takiego nakierowania badań przejawiał się wielokrotnie w jego pismach i był zgodny z „socjologizującą" tendencją pism marksistowskich myślicieli. A. Nowicki przyjmował, że byt społeczny jest pierwotny $\mathrm{i}$ konkretny, a istnienie wyizolowanej jednostki jest względem bytu społecznego wtórne i abstrakcyjne ${ }^{3}$. Znaczy to, że jeśli badania mają ujmować rzeczywiste podłoże zjawisk, trzeba rozpatrywać religię przede wszystkim na gruncie jej oddziaływania społecznego, zaś koncepcje danego myśliciela (np. krytyka religii) należy rozpatrywać w relacjach do innych ludzi i grup społecznych.

A. Nowicki zaczerpnął od K. Marksa również metaforę religii jako „opium ludu” ${ }^{\prime 4}$. Wedle koncepcji marksistowskich religia jest narzędziem ucisku klasy panującej nad klasą podporządkowaną. Nowicki porównuje religię do opium, ponieważ wierzenia o bogach „, usypiają" rewolucyjne dążenia ludu i stanowią kojące remedium na ich troski: podsuwając uciskanemu robotnikowi nierealny obraz nadprzyrodzonego porządku, zniechęca się go do walki o zmianę swoich warunków bytowych oraz niesprawiedliwych stosunków społecznych. Religia daje fałszywą pociechę, odwołującą się do raju, którego nie ma; ubogi robotnik będzie miał bogatego Boga i sowitą zapłatę w raju. A. Nowicki podkreślał, że metafora opium działa także w drugą stronę - wedle niego narkotyczne działanie religii uwidacznia się również w postawie klasy panującej, która za pomocą religii łatwo i fałszywie usprawiedliwia swoją pozycję i postępowanie. Z tych powodów religia konserwuje porządek społeczny. Inną społeczną funkcją religii, na którą A. Nowicki zwracał dużą uwagę, jest funkcja uświęcająca. Sednem „uświęcania" doktryn, organizacji, osób czy relacji społecznych było wyłączanie ich spod krytyki, dyskusji i debaty. A. Nowicki pisał, iż religia jest nie tylko opium, ale bywa też "dynamitem", który burzy panujące stosunki społeczne ${ }^{5}$. Autor dodawał, że „w przeszłości niektóre ruchy rewolucyjne wyrażały swoje dążenia językiem religijnym”" ${ }^{\prime 6}$, co można było zaobserwować w przypadku wojen chłopskich w Niemczech.

A. Nowicki traktował religię jako mistyfikację. Ludzki umysł odbija rzeczywistość, zaś w świadomości religijnej owo odbicie jest zniekształcone, ponieważ w nim znajdują się nieistniejące bóstwa. Pojęcie mistyfikacji odnosi się do owego zniekształcenia, przy czym Nowickiego najbardziej interesowały zniekształcenia zamierzone w celu wprowadzenia innych w błąd, np. kiedy odwołujemy się do hierarchii w niebie, aby uzasadnić panowanie hierarchii ziemskiejా. Stąd krytyka "nieba” staje się krytyką „ziemi”. Z powyższych racji A. Nowicki darzył szczególną atencją i szacunkiem Euhemera, twórcę koncepcji, wedle której bogowie są w rzeczywistości władcami (lub przodkami czy bohaterami), deifikowanymi po śmierci lub nawet za życia. A. Nowicki widział w euhemeryzmie jedną z głównych kategorii radzieckiego i marksistowskiego religioznawstwa.

Nowickiego interesowały wszelkie rodzaje krytyki religii, a przede wszystkim te, które wychodzą ze stanowisk ateistycznych. To zainteresowanie wynikało nie tylko stąd, że sam był ateistą i nigdy tego nie krył, ale również stąd, że traktował ",naukowy ateizm” jako konsekwencję i warunek postawy racjonalistycznej. Ten pogląd uzasadniał tym, że podług racjonalizmu wszystko może być przedmiotem krytycznego namysłu rozumu, religia zaś ma cele odwrotne i chce wyłączyć określone rzeczy od krytyki ${ }^{8}$.

\section{PrZedMIOT BADAŃ histoRII ATEIZMU I KRYTYKI RELIGII}

Dlaczego powinno się zajmować w badaniach religioznawczych czymś takim jak krytyka religii i ateizm? A. Nowicki uzasadnia to argumentem, że aby zachować wiarygodny opis zjawisk religijnych, należy badać również stanowiska kry-

2 A. Nowicki, Nauczyciele, Lublin 1981, s. 26.

3 Tenże, Portrety filozofów w poezji, malarstwie i muzyce, Lublin 1978, s. 17

4 K. Marks, Przyczynek do krytyki heglowskkiej filozofii prawa, [w:] K. Marks, F. Engels, W. Lenin, O religii. Wybór, Warszawa 1984, s. 45; Zob. A. Nowicki, Metafora opium, „Euhemer - Przegląd Filozoficzny" 1963, nr 5 (36), s. 3-7.

5 Tenże, Ateizm, Warszawa, 1964, s. 93.

6 Tenże, Lenin o ateizmie i ateistach, ",Studia Religioznawcze” 1971, nr 4, s. 104.

7 Tenże, Wykłady o krytyce religii, Warszawa 1963, s. 49.

8 Tenże, Ateizm...., dz. cyt., s. 77. 
tykujące je, gdyż religie często samookreślały się w odniesieniu do owych stanowisk oraz za ich sprawą religie zmieniały się, wyłaniały nowe doktryny, a niekiedy nawet zanikały. Poza tym, ateizm wedle Nowickiego zawsze posiada jaką́ pozytywną treść, która nie ogranicza się do krytyki religii’, dlatego ateizm sam w sobie, niezależnie od jego związków z religia, zasługuje na uwagę uczonych. Ową pozytywną treść rozumiał w ten sposób, że skoro religia, będąc mistyfikacją, neguje zastaną rzeczywistość, to ateizm, jako coś, co przeczy religii, musi byćnegacją negacji, a co za tym idzie - czymś pozytywnym, umożliwiającym badanie i poddawanie pod osąd rozumu wszystkich zjawisk niezależnie od form, jakie one przybierają ${ }^{10}$.

W tym miejscu należy zapytać - czy historia ateizmu pokrywa się z historią krytyki religii albo całkowicie zawiera się w niej? Wedle Nowickiego, na te pytania należy odpowiedzieć negatywnie z dwóch powodów:

1) historia ateizmu nie pokrywa się z historią krytyki religii, ponieważ ateizm jest stanowiskiem przeczącym istnieniu bogów i sfery nadprzyrodzonej, a nie każdy krytyk religii był ateista. Jako przykład można wskazać Epikura z Samos, który przyjmował istnienie bogów, ale jednocześnie przeczył powszechnym wyobrażeniom o nich, ponieważ twierdził, że bóstwa nie ingerują w losy świata ${ }^{11}$. Innym przykładem może być Immanuel Kant, który przyjmował Boga jako postulat praktycznego rozumu, ale jednocześnie zasłynął swoimi zarzutami wobec dowodów na istnienie Boga (zwłaszcza tzw. dowodu ontologicznego) oraz krytykował wiarę w siłę modlitwy jako szkodliwą dla moralności ${ }^{12}$;

2) historia ateizmu nie zawiera się całkowicie w historii krytyki religii, ponieważ nie każdy ateista de facto krytykował religię oraz nie ma konieczności, ażeby dany ateista ją kontestował. Jest wiele przyczyn takiego stanu rzeczy, dotyczących zarówno realiów społecznych, jak celów i postaw samych ateistów. Ateizm nie wiąże sięz krytyką religii np. w przypadku indyferentyzmu religijnego, gdzie niewiara wynika z obojętności na sprawy religijne, a co za tym idzie, indyferentysta nie widzi powodu, dlaczego miałby krytykować coś, na co i tak nie zwraca uwagi. Ateista mógł również powstrzymywać się od krytyki religii z obawy przed sankcjami prawnymi, prześladowaniami lub utratą życia - według Nowickiego dotyczyło to przede wszystkim myślicieli renesansowych i starożytnych. Krytyk religii mógł powstrzymać się od zabrania głosu także dla władzy. W tym miejscu należy wspomnieć o Kazimierzu Łyszczyńskim, szlachcicu, jednym z pierwszych znanych polskich ateistów. W swoim traktacie pt. De non existentia Dei (z którego zostały jedynie fragmenty) pisał, że religia jest fałszem i kłamstwem. Stosownie do tego K. Łyszczyński dzielił ateistów na dwa rodzaje: na tych, którzy chcą rozerwać religijne więzy uciskające lud oraz na tych, którzy wykorzystują religię jako „pożyteczną bajkę" do sankcjonowania prawa, utrzymywania porządku społecznego i - przede wszystkim - zapewnienia sobie rozmaitych korzyści ${ }^{13}$.

Okoliczność, że ateizm i krytyka religii nie są tym samym, jest ważna dla zrozumienia głównego podziału krytyki religii, jaki przyjmował A. Nowicki. Istnieją cztery zasadnicze rodzaje stanowisk, z których poddawano religię krytyce ${ }^{14}$. Wpierw należy rozpatrzyć, czy krytyka religii dokonuje się „,wewnątrz” niej, czy „,z zewnątrz”, ti. czy sama krytyka wychodzi z przesłanek i zasad religijnych, czy irreligijnych. W pierwszym przypadku mamy do czynienia z krytyką konserwatywno-apologetyczną albo religijno-reformatorską. Pierwszy rodzaj krytyki wyraża tendencje zachowawcze przedstawicieli danej religii, których celem jest ochrona tradycji przed wrogimi siłami, nie tylko ze strony niewierzących, ale również ze strony religijnych innowatorów i heretyków. Szymon Starowolski twierdzit, że herezje biorą się z „nowinek” ${ }^{\prime \prime}$ - w tym kontekście, słowo „bezbożność" lub „ateizm” mogłoby zastąić „herezje”. Z kolei krytyka religijno-reformatorska stanowi jedno ze źródeł zmian religii, a dokonywana przezeń krytyka ma na celu przekształcenie jej i zrewidowanie dorobku tradycji. Tak jak w przypadku krytyki konserwatywnej, mamy do czynienia z pewną formą „,samokrytyki”, choć ona nie służy konsolidowaniu religii w takiej postaci w jakiej była znana, ale na wprowadzeniu do niej nowych elementów. Można wskazać jako przykład Marcina Lutra, który jako augustianin wykształcił się w ramach Kościoła, lecz dążył do zerwania z nim i uformowania nowego ruchu religijnego.

W przypadku zewnętrznej krytyki religii możemy mieć do czynienia z krytyką antyreligïną albo dialektyczną. Krytyka antyreligijna jest jednoznacznie przeciwna religii jako takiej. A. Nowicki często określał taki rodzaj krytyki jako „powierzchowny" $i$, wulgarny”. Wedle redaktora naczelnego „Euhemera”, bywały okresy dużego zapotrzebowania społecznego na krytykę antyreligijna, która przez to mogła pełnić role postępowe, choć sama z siebie niewiele wnosiła. Krytycy antyreligijni

9 A. Nowicki, Przedmiot i zadania historii ateoorafii, „Euhemer - Przegląd Religioznawczy” 1966, nr 5 (54), s. 3-4.

10 A. Nowicki, Ateizm..., dz. cyt., s. 77.

11 Diogenes Laertios, Żywoty i poglądy stynnych filozofów, Warszawa 2004, s. 644.

12 Z. Kuderowicz, Kant, Warszawa 2000, s. 102.

13 A. Nowicki, Wykłady o krytyce religii w Polsce, Warszawa 1965, s. 59.

14 Tenże, Ateizm..., dz. cyt., s. 37-41

15 Sz. Starowolski, Braterskie napomnienie ad dissidentes in religione, [w:] Z. Ogonowski (red.), Filozofia i myśl społeczna XVII w. Część pierwsza, Warszawa 1979, s. 518.

Ogrody NAUK I SZTUK NR 2014 (4) 
często w ogóle nie widzieli w religii niczego dobrego. Reprezentantem takiej postawy może być Christopher Hitchens, którego książka Bóg nie jest wielki nosi podtytuł Jak religia zatruwa wszystko. Krytyce antyreligijnej A. Nowicki przeciwstawiał krytykę dialektyczna, którą określał jako wszechstronną krytykę religii ze stanowisk irrreligijnych. Podstawową różnicą między postawą antyreligijną a dialektyczną jest ich nastawienie, ponieważ ta pierwsza skupia się na odrzucaniu treści religii, druga zaś usiluje z krytykowanego stanowiska wydobywać rzeczy cenne i wartościowe. Z tego względu cele obu krytyk różnią się - jedna ma cele negatywne, sprowadzające się do obalenia jakichś twierdzeń, a druga chce intelektualnie "Wzbogacić się" i „nauczyć" od krytykowanego stanowiska, przejmując coś od niego. Krytyka dialektyczna jest wszechstronna z tego tytułu, że odróżnia w krytykowanej religii to, co w niej cenne, od tego, co godne odrzucenia, wartościowość zaś owego stanowiska polega na tym, że chce przyswoić sobie owe cenne treści. Wedle Nowickiego sztandarowymi reprezentantami krytyki dialektycznej są klasycy marksizmu.

Autorowi Portretów filozofów najblizszy był ostatni rodzaj krytyki religii. Pierwszym powodem było nawiązanie - już w samej nazwie - do tradycji materializmu dialektycznego, zwłaszcza do uwag W. Lenina, wedle którego stanowisko materialistyczno-dialektyczne nie sprowadza się do odrzucania przedmiotu krytyki, lecz dąży do poprawiania i przejmowania tego, co w nim cenne ${ }^{16}$. Nie mniej, ważny wydaje się inny aspekt, związany ze sposobem ujmowania kultury świeckiej przez Nowickiego. Jeżeli ateizm - jak referowaliśmy wyżej- ma treść pozytywna, polegającą „na przywróceniu rozumowi ludzkiemu swobody badania wszelkich treści bez względu na ich formę $e^{\prime \prime 17}$ oraz na tym, że wynikająca zeń krytyka religii wyrasta z pewnych etycznych i aksjologicznych rozstrzygnięć, to kultura świecka zasługuje na miano „kultury prawdziwej". Rozwój tej kultury byłby wspierany przez dialektyczną krytykę religii, gdyż wydobywałaby z krytykowanej religii treści, które byłyby cenne i byłyby zdolne do „roztopienia się" w ramach kultury świeckiej. Przykładem mogą być rozważania Nowickiego wokół teologii Eucharystii1" ${ }^{18}$ według niego, teologia Eucharystii wyraża pewną prawdę ontologiczną-antropologiczną (choć w zniekształconej, religijnej formie), że człowiek może być realnie obecny w rzeczach, a szczególnie we własnych dziełach $\mathrm{i}$ wytworach.

\section{RODZAJE KRYTYKI RELIGII I NAJWAŻNIEJSZE DYREKTYWY BADAWCZE}

A. Nowicki drobiazgowo podejmował kwestie metodyki badań religioznawczych. W związku z tym sformułował wiele rozmaitych wskazówek, w jakim kierunku należy je prowadzić oraz dokonał wielu klasyfikacji w obrębie ateizmu i krytyki religii. Podstawową rolę pełnił czwórpodział przedstawiony w poprzedniej części pracy.

Niemniej ważne było wskazanie, czy badany myśliciel był ateista, czy nie. Wydaje się, że kwestia jest trywialna i wystarczy wykazać, czy autor zaprzeczał istnieniu istot i sfery nadprzyrodzonej, czy nie. Sprawę jednak komplikuje parę okoliczności, których historyk krytyki religii powinien być świadomy. Zwróćmy uwagę, że znaczenie terminu „ateizm” zmieniało się na przestrzeni dziejów. Chrześcijanie żyjący w starożytnym Rzymie byli oskarżani o ateizm, ponieważ nie chcieli oddawać boskiej czci władcom Imperium. Niekiedy nawet między odłamami chrześcijaństwa (np. katolikami a protestantami) padały zarzuty o ateizm (sic!), co w tym kontekście można uznać za wyrażenie synonimiczne do „bluźnierczy" lub ",bezbożny". Epikur twierdził, że bogowie istnieja, ale przeczył, by byli supra naturam. Niekiedy za ateistę uchodził ktoś, czyj system filozoficzny dawał teoretyczne podstawy tym wizjom świata, które (w znacznym stopniu lub zupełnie) były pozbawione odniesień do Boga. Przykładem może być Kartezjusz - chociaż on formułował dowody na istnienie Boga i był przekonany o jego istnieniu, to został nazwany „drugim Vaninim"19, ponieważ jego fizyka w niewielkim stopniu uwzględniała sprawcze działanie Boga w świecie. Powodem zastosowania takiego określenia do Kartezjusza była jego mechanicystyczna fizyka, w której rola Boga ograniczała się do nadania pierwszego impulsu całemu systemowi ruchu w przyrodzie. Dość wspomnieć, że Julien Offray de La Mettrie, jeden z radykalnych przedstawicieli materializmu mechanistycznego, XVIII-wieczny filozof, lekarz, ateista i libertyn, uważał się za „,kartezjanina”.

Określenie, czy mamy do czynienia z ateista, może być dodatkowo utrudnione przez działania samego myśliciela, który maskuje swoje prawdziwe poglądy. Myśliciel może tworzyć tzw. „,konteksty ochronne”, które przybierają rozmaitą postać. Mogą to być deklaracje wyrażające pragnienie bycia w zgodzie z Pismem Świętym i zasadami wiary. Interesujące strategie obierał Giulio Cesare Vanini. Przytaczał w swoich dziełach tezy i twierdzenia znanych ateistów, z którymi się zgadzał, lecz „oficjalnie" ograniczał się jedynie do samego referowania twierdzeń różnych bezbożnych myślicieli, bez ich akceptacji. To, co wyglądało jedynie na przytaczanie pewnych stanowisk, z którymi G. C. Vanini oficjalnie się nie

16 A. Nowicki, Lenin o ateizmie..., dz. cyt., s. 105.

17 Tenże, Ateizm..., dz. cyt., s. 77.

18 Tenże, Spotkania w rzeczach, Warszawa 1991, s. 305-316.

19 Tenże, Centralne kategorie filozofii Vaniniego, Warszawa 1970, s. 202. 
zgadzał, de facto było głoszeniem własnego zapatrywania na kwestie filozoficzne. Żeby wyrażać własne przekonania, G. C. Vanini stosował również zdania hipotetyczne, takie jak „Gdybym nie był chrześcijaninem, to twierdziłbym, że świat jest wieczny" ${ }^{\prime 20}$. Podobnym kontekstem ochronnym ateisty może być celowe bronienie prawd teologicznych słabymi argumentami. Na kartach swego Amfiteatru G. C. Vanini odrzucił tradycyjne dowody na istnienie Boga, ponieważ są zbyt słabe wobec ataków ateistów. W związku z tym przedstawił własny, , ,kabalistyczny" dowód istnienia Boga z doskonałości liczby dziewięćc $c^{21}$. Dowód polega na tym, że sugeruje się istnienie głębokich i ukrytych znaczeń dziewiątki (na przykład to, że gdy ciąg dziewięciu liczb od 2 do 10 rozbijemy na dwa ciagi liczb od 2 do 7 oraz od 8 do 10 , to gdy zsumujemy liczby w obu ciaggach, otrzymamy po 27 , a przecież 9 pomnożone przez pierwiastek z 9, daje 27), a następnie z tego, że istnieje 9 sfer niebieskich, 9 chórów anielskich i 9 kategorii diabłów, wnosi się o tym, że 9 wskazuje na doskonałość świata, zaś owa dziewiątka, żeby była dziesiątka, czyli pełnią doskonałości, wymaga jedynki, czyli Boga. A zatem mimo deklaracji dowiedzenia, że Bóg naprawdę jest, G. C. Vanini sugerował, że kabalistyczne spekulacje są równie dobrym argumentem wskazującym na istnienie Boga, jak klasyczne dowody.

Wedle A. Nowickiego, dany obiekt jest ludzkim dziełem, jeżeli jest wytworem pracy danego człowieka i zawiera istotne cząstki jego osobowości (np. idee jego filozofii, ekspresje jego postawy wobec świata, przeżycia psychiczne). Teza o obecności człowieka w jego dziełach miała wydźwięk ontologiczny: owo „bycie-w-dziele" nie ma charakteru semiotycznego, będącego jedynie oznaką czyichś przeżyć lub znakiem odnoszącym do człowieka będącego poza artefaktem (np. ksiązi) - człowiek jest realnie obecny w swoich dziełach"2, a zatem zdania "Czytam Mickiewicza" i „Czytam wiersze Mickiewicza" znaczą to samo. Wynika stąd, że kulturę należy ujmować podmiotowo; świat dzieł ludzkich, czyli świat kultury jest naprawdę światem „ludzi w rzeczach” (cultura est homo in rebus), dlatego należy dokładnie identyfikować autorów danych koncepcji oraz badać, jaki status pełni owo przekonanie lub argumentacja w całokształcie idei danego myśliciela. Na podstawie tezy o realnej obecności człowieka w wytwarzanych dziełach (ergantropii), Nowicki wnioskuje, że nie ma „myśli niczyich", istniejących poza czasem i przestrzeniąa23 - zarówno ludzie, jak książki są bytami czasoprzestrzennymi. Zwróćmy uwagę, że takie radykalne stwierdzenia nie pozwalają uznać Nowickiego za "typowego" czy „ortodoksyjnego" marksistę.

A. Nowicki wielokrotnie powtarzał, że istnieją rozmaite sposoby istnienia w dziełach. Przykładowo, według niego, w monografii Martina Heideggera o Friedrichu Nietzschem, realnie obecny jest zarówno M. Heidegger, jakF. Nietzsche, choć żaden z nich nie zetknął się z drugim osobiście. Nowicki przyjmował ontologię relacyjna, wedle której istota i właściwości danej rzeczy są konstytuowane przez relacje z innymi rzeczami ${ }^{24}$. W odniesieniu do ludzi oznacza to, że adekwatny opis (danego) człowieka wymaga ujęcia go w relacjach z innymi. Mówiąc wprost: człowiek jest tworzony przez spotkania z innymi ludźmi, przy czym A. Nowicki spotkanie rozumiał szeroko, obejmując tym pojęciem również spotkania autorów z czytelnikami, niezależnie od lat, które ich dziela. Właśnie z tego względu A. Nowicki twierdzit, że byt społeczny jest pierwotny wobec bytu jednostkowego, indywidualnego. Co za tym idzie dla metodologii historii idei: każda obecność jest współobecnością i należy rozpatrywać badane koncepcje w kontekście interpersonalnym. W praktyce oznacza to, że badając np. idee G. C. Vaniniego, należy nie tylko skupiać się na samych jego twierdzeniach, ale również zwracać uwagę, przeciw komu on formułuje zarzuty, do kogo nawiązywał, czyje argumenty powtarza, a którymi się inspiruje do tworzenia własnych, kto przyjmował jego tezy, kto rozwijał jego koncepcje, na kogo G. C. Vanini się powołuje, na kogo jego idee oddziaływały, w jaki sposób jego koncepcje były poruszane w społeczeństwie, kto poza Vaninim jest jeszcze obecny w jego dziełach, etc. A. Nowicki twierdzi, że badanie poglądów danego krytyka religii „,w izolacji” od innych ludzi, jest badaniem niewłaściwym, nieadekwatnym.

Należy dodać, że historyk krytyki religii nie powinien ograniczać się do analizy pism filozoficznych. Ludzka obecność w rzeczach przybiera różne formy i pojawia się również w poezji, rzeźbie, muzyce, malarstwie, filmach, dramacie, itp. Chodzi zatem o to, że badacz zajmujący się np. filozofią religii Giordana Bruna nie powinien analizować tylko jego stricte filozoficznych dzieł, ale powinien też poszukiwać owych idei w jego utworach poetyckich, a także w dziełach sztuki, które o nim stworzono. Jeśli ktoś interesuje się jego heroistyczna, antyreligijną etyka, badacz tej koncepcji może odnieść się do poezij, ponieważ popularnym wątkiem w poezji jest śmierć G. Bruna na stosie za głoszone poglądy ${ }^{25}$.

Jeżeli religiajest forma, dzięki której pozareligijne treści są dane w nadprzyrodzonej szacie, zadaniem historyka krytyki religii jest odkrycie, o jakiego rodzaju treść tu chodzi. A. Nowicki wyróżniał cztery rodzaje takich demistyfikujących teorii:

20 Tamże, s. 60.

21 Tamże, s. 143-144

22 Tenże, Człowiek w świecie dzieł, Warszawa 1974, s. 6.

23 Tenże, Portrety..., dz. cyt., s. 13.

24 Tamże, s. 17-18.

25 Zob. Tenże, Bruno i Vanini w śziecie poezji, dramatu i muzyki, „Euhemer - Przegląd Religioznawczy” 1970, nr 2 (76), s. 55-68.

Ogrody NAUK I SZTUK NR 2014 (4) 
euhemeryzm, theagenizm, metrodoryzm i prodykizm ${ }^{26}$. Ich wspólnym rysem jest to, że nazwy tych koncepcji pochodzą od imion greckich uczonych oraz że każda z nich odpowiada na pytanie „o czym tak naprawdę mówią religie”. Jest to typ krytyki religii poprzez wskazywanie jej naturalnych źródeł, pozbawionych nimbu nadprzyrodzoności. Zwróćmy uwagę, że kiedy twierdzimy, że gdy uda nam się ustalić naturalny (ț. taki, który nie jest nadprzyrodzony) sposób powstania idei Boga, tym samym wskażemy na jej fałszywość (a w konsekwencji, że Boga nie ma), to popadamy w błąd znany w logice jako „błąd genetyczny”. Niemniej, nie zmienia to faktu, że tego rodzaju teorie niejednokrotnie powodowały utratę wiary (pamiętajmy też, że nie każda teoria genetyczna musi przyjmować, że religia jest mistyfikacją).

Wedle euhemeryzmu, bogowie są w rzeczywistości deifikowanymi władcami, przodkami i bohaterami. Euhemer uważał, że cześć (lub strach) otaczająca władców i bohaterów niejednokrotnie rosła i rosła, aż w sposób wyolbrzymiony przekroczyła granice kondycji śmiertelnych, co w efekcie czyniło ich istotami nie z tego świata, nadludzkimi, czyli boskimi. Z tego tytułu euhemeryzm uważa bóstwa za mistyfikacje historyczne i społeczne. Theagenes z Rhegion odczytywał Homera alegorycznie, uznając, że pojawiające się imiona bóstw symbolizują żywioły i siły natury: Hefajstos reprezentował ogień, Posejdon wodę, itp. A. Nowicki na podstawie tej koncepcji sformułował pojęcie theagenizmu, wedle którego bogowie są mistyfikacją kosmologii (lub jak powiedzielibyśmy współcześnie-fizyki, przyrodoznawstwa). Inny charakter miała koncepcja Metrodora z Lampsakosu, który twierdzit, że bogowie są personifikacjami uczuć, doznań, stanów ducha lub cech psychicznych. Mitologia Greków dostarcza wielu przykładów - Hypnos jako bóstwo snu, Atena jako bogini mądrości, porywczość Aresa, itd. Azatem metrodoryzm jest teorią uważającą bogów za mistyfikację treści psychologicznych. Prodikos z Keos głosił czwartą koncepcję, iż w bóstwa przeistacza się to, co jest dla ludzi cenne, co przynosi im pożytek i co jest obiektem ich dążeń oraz aspiracji. Wedle tej teorii Dionizos jest personifikacją wina ijego pożytków, Dike jest personifikacją sprawiedliwości, Nike - zwycięstwa, itd. Wedle prodykizmu bogowie są mistyfikacją aksjologii.

Spośród powyższych koncepcji A. Nowicki uznawał euhemeryzm za najważniejsza, co wynikało m.in. z jego pozycji marksistowskich oraz przyznania prymatu temu, co społeczne nad tym co jednostkowe (także na gruncie ontologicznym). Uznanie dla euhemeryzmu implikowało nacisk, jaki wedle Nowickiego powinien położyć historyk krytyki religii na badanie społecznych funkcji religii, a w szczególności: przez jakie klasy religia jest uznawana i głoszona, kto czerpie z niej korzyść, czy podtrzymuje porządek społeczny, itp.

A. Nowicki nazywał ",entralnymi kategoriami” najważniejsze narzędzia pojęciowe, które myśliciel stosował przy swoich rozważaniach. Według Autora Ateizmu, zadaniem historyka jest wyodrębnienie i analiza owych kategorii od pozostałych pojęć, jakimi dany filozof posługiwał się. Szczególny nacisk był położony na rozeznanie w się w sposobach, na jakie dany myśliciel je używał. Było to zgodne z ogólną tendencją pism autora Portretów filozofów, żeby historyk nie referował po prostu cudzych idei, ale żeby dobrze dawał wyraz czyichś przebiegów myślowych oraz by należycie odzwierciedlał czyjeś sposoby formułowania myśli poprzez przedstawianie, w jaki sposób dane pojęcie było stosowane.

Religia wedle Nowickiego posiada sześć komponentów - wyobrażeniowy (mity), instytucjonalny (kler), czynnościowy (rytuały i obrzędy), emocjonalny (przeżycia), doktrynalny (dogmaty) i aksjologiczny (normy moralne)27. Historyk krytyki religii powinien wskazywać, na jaki element religii pada krytyka - przykładowo, kiedy I. Kant krytykował modlitwę, poruszał element czynnościowy i aksjologiczny. Należy stosować również podział na ateizm teoretyczny i praktyczny ${ }^{28}$. Pierwszy jest intelektualną negacją Boga, a sednem ateizmu praktycznego jest życie w taki sposób, jakby Boga nie było. To ma znaczenie w określaniu postaw niektórych myślicieli. Przykładowo, wedle F. Nietzschego głównymi racjami odrzucenia Boga są nie wyrozumowane racje, lecz szkodliwośćidei Boga dla (pełnego, twórczego) życia. Z pomniejszych dyrektyw badawczych należy wspomnieć m.in., że: trzeba określić stopień postępowości, naukowości i spójności danej krytyki religii, określić rodzaje używanych argumentów, ustalić, czy krytyk religii dążył do utworzenia „ateistycznej religii” (jak Kult Rozumu w rewolucyjnej Francii), określić czy mamy do czynienia z właściwym ateizmem, czy indyferentyzmem, ustalić przyczyny niewiary danego autora oraz analizować (faktyczne) skutki dokonanej krytyki, co ona spowodowała w obrębie danej społeczności ${ }^{29}$.

Ateografia, ATEOZNAWSTO I ATEOMETRIA

Należy przedstawić trzy szczególnie oryginalne pojęcia stworzone i opracowane przez Nowickiego. Wedle niego, badacz ateizmu nie powinien zajmować się wyłącznie historią samego ateizmu i doktryn ateistycznych. Powód jest pro-

26 Tenże, Ateizm..., dz. cyt., s. 59-61.

27 Tamże, s. 11.

28 Tamże, s. 109

29 Zob. Tenże, O metodach i zadaniach historii religii, „E Euhemer, Przegląd Religioznawczy - Zeszyty Filozoficzne” 1960, nr 1, s. 3-12. 
sty: na kształt idei religijnych (oraz irreligijnych) wpływało nie tylko to, co robili i pisali ateiści, ale również to, jaka była recepcja ich dzieł oraz jak ich postrzegano. Zapotrzebowaniu na tę lukę badawczą odpowiada historia ateografii jako subdyscyplina historii krytyki religii. Wedle Nowickiego „Warunkiem zakwalifikowania danego tekstu do ateografii nie jest ateistyczna treść danego tekstu (...), ale tylko i wyłącznie obecność rozważań o ateizmie i ateistach"30. Wynika stąd, że przedmiotem tekstu ateograficznego są klasyfikacje ateizmu, rozważania dotyczące definicji ateizmu itp. Trzeba pamiętać przy tym, że tekst ateograficzny to nie jest po prostu tekst, w którym występuje słowo „ateista” lub „ateizm”; z drugiej strony, te dwa słowa w ogóle nie muszą występować, ponieważ zamiast nich mogą znajdować się terminy jak „,bezbożnik", ,,bluźnierca”, itp.

Należy zdecydowanie odróżnić tekst ateograficzny od ateistycznego. Teksty ateistyczne to takie, których treść zaprzecza istnieniu bogów i świata nadprzyrodzonego, a autor tekstu ateograficznego wcale takiej treści zaprzeczać nie musi. Zapiski dotyczące rodzajów i wartości ateizmu może sporządzić zarówno wierzący, jak niewierzący. Jakob Friedrich Reimmann, luterański teolog i autor dzieła Historia universalis atheismi et atheorum, był tak samo ateografem, jak Pierre Sylvain Maréchal, publicysta, rewolucjonista, ateista i autor Dictionnaire des athées anciens et modernses. Należy również oddzielić historię ateizmu od historii ateografii: „Historyk ateizmu bada ateizm, natomiast historyk ateografii bada odbicie ateizmu, sposób recepcji dzieł ateistycznych, echa działalności ateistów"31. Owo „odbicie” należy rozumieć w kategoriach marksistowskich, jako subiektywną reprezentację i odwzorowanie obiektywnie istniejącej rzeczywistości w umyśle. Należy przypomnieć, że historia ateografii nie opiera się wyłącznie na traktatach filozoficznych czy pismach społecznych, ale również na innych dobrach kultury, jak poezji, malarstwie, muzyce, itp.

A. Nowicki proponował, aby wśród ateografów wyróżnić ateoznawców. Wedle niego ateoznawcami są ateografowie, którzy przekazują nam wiarygodne wiadomości dotyczące ateistów i ich doktryn ${ }^{32}$. Wynika stąd, że każdy ateoznawca jest ateografem, lecz nie każdy ateograf jest ateoznawcą (przy czym ateoznawca również nie musi być ateistą). Ten stan rzeczy jest uzasadniony okolicznościa, że historyk ateografii musi spostrzec, że rzeczywistość społeczna, która odbija się w umysłach ludzi, niekiedy bywa zniekształcona. W związku z tym, badacz ateizmu, który chce odtworzyć pewne fakty dziejowe na podstawie dawnych relacji, powinien należycie oddzielać od siebie informacje wiarygodne od niewiarygodnych. Z drugiej strony, historyka krytyki religii mogą interesować same wyobrażenia o danym ateiście, niezależnie od ich słuszności lub niesłuszności - przykładowo, Nowickiego interesowało to, jak postrzegany był po śmierci G. C. Vanini, któremu wielu teologów nadawało miano aquila atheorum, czyli „orzeł [wśród] ateistów”, co sugeruje, jakoby w przekonaniu teologów XVII i XVIII w. G. C. Vanini był pierwszym pomiędzy tymi, którzy twierdza, że Boga nie ma, czyli że wedle nich nazwisko G. C. Vaniniego było wręcz synonimem ateizmu ${ }^{33}$.

A. Nowicki postulował prowadzenie badań ateometrycznych. W jego koncepcji ateometria miała być nauką pomocniczą dyscyplin ateoznawczych, uściślająca jej twierdzenia ${ }^{34}$. Ateometria to nauka zajmująca się kwantytatywnymi i mierzalnymi aspektami ateizmu, a jej zadaniem w szczególności jest zdobywanie danych ilościowych i ich analiza. Zadaniem tej dyscypliny jest badanie występowania ateistów i ich tekstów, porównywanie wyróżnionych elementów tych dzieł oraz różnorakie „mierzenie" $\mathrm{i}$ „,porównywanie" obecności ateistów w kulturze $\mathrm{e}^{35}$. Badania ateometryczne polegają przede wszystkim na analizie czytelnictwa, określaniu liczby danych dzieł i ich lokalizacji, statystyce określonych pojęć w ateistycznym lub ateograficznym tekście, rejestrze wzmianek o danym autorze, badaniach stylometrycznych itp.

\section{Podsumowanie}

Jak można było przeczytać, metodologia badań Nowickiego nad historią ateizmu i krytyki religii była zaawansowana i szczegółowa. Obejmując zasięgiem wszystkie epoki cywilizacji, dążył on do drobiazgowego ujęcia wybranych stanowisk, kładąc nacisk na społeczne aspekty i funkcje religii oraz formy jej kontestacji. Samo ukonstytuowanie i wyróżnienie dyscypliny naukowej, jaką jest historia krytyki religii, należy potraktować jako istotny wkład Nowickiego w religioznawstwo. Tym samym, socjologizujący charakter jego doktryny stanowi uzupetnienie rozmaitych psychologicznych koncepcji religii oraz nurtów, które pomijały społeczne konteksty funkcjonowania religii, zwłaszcza dotyczące sporów między wie-

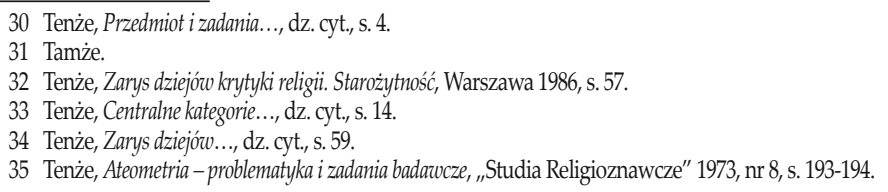

Ogrody NAUK I SZTUK NR $2014(4)$ 
rzącymi a niewierzącymi. Metodologia Nowickiego obejmuje szeroki zestaw narzędzi pojęciowych do badania dziejów irreligijności i już z tego tytułu jest bogata i płodna. Nota bene, autor Spotkań w rzeczach twierdzit, że główną wartością dzieł jest ich płodność i zdolność inspirowania do kolejnych myśli ${ }^{36}$.

Z pewnością można postawić kilka zastrzeżeń wobec jego metodologii - niektórym może nie odpowiadać jego zaangażowany „wojujący ateizm”. Można również podnieść zarzut, że używane przez niego kategorie marksistowskiego religioznawstwa są przestarzałe lub zgoła nieadekwatne (zwłaszcza dla tych, których mniej interesuje społeczny aspekt religii). Zwolennicy fenomenologii i hermeneutyki z pewnością będą widzieć w jego stanowisku daleko posunięty redukcjonizm, przez który umyka wiele aspektów zjawisk religijnych.

Niemniej, nie zmienia to faktu, że warsztat pojęciowy Nowickiego jest cennym nabytkiem dla badań religioznawczych. Co więcej, jego koncepcje metodologiczne można rozszerzyć na inne dyscypliny badawcze. Niektóre kategorie, po mniejszych lub większych modyfikacjach, mogłyby dobrze sprawdzić się jako narzędzia pojęciowe do badań nad historią idei politycznych, społecznych lub filozoficznych oraz do badania dziejów ich krytyki. Ponad tym wszystkim należy pamiętać, że A. Nowicki zostawił po sobie oryginalną filozofię kultury, głoszącą realną obecność człowieka we własnych dziełach oraz że człowiek jest tworzony przez spotkania z innymi, en face lub spotykając ludzi w ich dziełach. Już z samych tych dwóch powodów - płodności jego metodologii oraz oryginalności filozofii - warto czytać Nowickiego.

\section{Bibliografia}

\section{Teksty źródłowe}

[1] Nowicki A., Ateizm, Warszawa 1964.

[2] Nowicki A., Ateometria - problematyka izadania badawcze, ,"Studia Religioznawcze" 1973, nr 8.

[3] Nowicki A., Bruno i Vanini w śzwiecie poezii, dramatu i muzyki, „Euhemer-Przegląd Religioznawczy" 1970, nr 2 (76).

[4] Nowicki A., Centralne kategorie filozofi Vaniniego, Warszawa 1970.

[5] Nowicki A., Człowiek w świecie dziet, Warszawa 1974.

[6] Nowicki A. Lenin o ateizmie iateistach, Studia Religioznawcze" 1971, nr 4

[7] Nowicki A., Metafora opium, „Euhemer-Przegląd Filozoficzny" 1963, nr 5 (36).

[8] Nowicki A., Nauczyciele, Lublin 1981.

[9] Nowicki A., O metodach i zadaniach historii religii, „Euhemer, Przegląd Religioznawczy - Zeszyty Filozoficzne” 1960, nr 1.

[10] Nowicki A., Portrety filozofów w woezii, malarstwie imuzyce, Lublin 1978.

[11] Nowicki A., Przedmiot izadania historii ateografii, ,Euhemer - Przegląd Religioznawczy" 1966, nr 5 (54).

[12] Nowicki A., Spotkania w rzeczach, Warszawa 1991.

[13] Nowicki A., Wykkady o krytyce relizii w Polsce, Warszawa 1965.

[14] Nowicki A., Wykkady o krytyce religii, Warszawa 1963.

[15] Nowicki A., Zarys dziejórw krytyki religii. Starożytność, Warszawa 1986.

\section{Książki/ czasopisma}

[16] Diogenes Laertios, Żywoty i pogladdy slynnych filozofów, Warszawa 2004.

[17] Kuderowicz Z., Kant, Warszawa 2000.

[18] Marks K., Przyczynek do krytyki heglowskkie filozofii prawa, [w:] Marks K., Engels F., Lenin W., O religii. Wybór, Warszawa 1984.

[19] Starowolski Sz., Braterskie napomnienie ad dissidentes in religione, [w:] Ogonowski Z. (red.), Filozofia i myśl spoteczna XVII w. Część pierwsza, Warszawa 1979.

[20] Życiorys Andrzeja Nowickiego, „Euhemer - Przegląd Religioznawczy" 1979, nr 4 (114).

36 Tenże, Spotkania $w$..., dz. cyt., s. 425. 